\title{
Influence Temperatur of Pyrolisis Process on Production of Liquid Smoke from Candlenut Shell by Examining its Potensial Coumpound
}

\author{
Sulhatun, Rosdanelli Hasibuani, Hamidah Harahap, Iriani
}

\begin{abstract}
The purpose of this research particularly to acknowledge characteristic of product pyrolysis at conditions that give best yield of liquid smoke products maximum resulted during pyrolisis process biomassa tempurung kemiri . This Research conducted on a fixed batch reactor made of metal plate with a thickness $3.0 \mathrm{~mm}$. It carries $200 \mathrm{kgs}$ in capacity. In this phase, the moisture of candlenut shells might be kept in 10 $12.5 \%$ wt. Process temperatur divariasikan pada suhu $350{ }^{\circ} \mathrm{C}$, $450{ }^{\circ} \mathrm{C}$, dan $550{ }^{\circ} \mathrm{C}$. serta variasi waktu pyrolisa pada $15,30,45$ until 435 menute. Identifikasi product by GCMS at optium condition untuk mengetahui komponen senyawa pyrolisa yang dihasilkan.The result of the risecrch adalah The best process condition of liquid smoke maximum during pyrolisis of candlenut shell by using pyrolisis methode at time 3,5 hourss and Temperature $450 \mathrm{C}$. From this research conclussion can be described as followes The best process condition of liquid smoke maximum during pyrolisis of candlenut shell by using pyrolisis methode at time 210 menute and Temperature 450 OC and identification of products by using GCMS (GC Mass Spectrometry) at optimum condition at temperature $450{ }^{\circ} \mathrm{C}$. and time pyrolisis 210 menute is showed that liquid smoke candle nut. Results of GC-MS analysis on liquid smoke of the hazelnut shell of the pyrolysis process at 350 OC obtained 10 components consisting of 2 acidic components, 2 components of the ketone group and the Aldehid, 3 components of the phenols, and 1 component of the Benze Zero. At the temperature of pyrolysis 450 OC obtained. 7 components consisting of 1 acidic component, 3 components of ketone and aldehydes, 2 components of the phenols, and 1 component of the formaldehyde class and at Suhupirolisis 550 0C obtained 12 components consisting of 3 components of the group Acids, 5 components of the ketone and aldehyde, 2 components of the phenols, and 2 components of the benzenol. The temperature effect that provides the best compound composition with the lowest amount of compound composition is the 7 components with the highest phenol level at $4500 \mathrm{C}$. There is no content of Benzo@ pyrine compound in the composition of liquid smoke shell of candlenut.
\end{abstract}

Revised Manuscript Received on October 15, 2019.

* Correspondence Author

Sulhatun, Student of Doctoral Program in Chemical Engineering Department, Faculty of Engineering, University of North Sumatra, Medan, North Sumatera, Indonesia.

Rosdanelli Hasibuani, Lecturer of the Doctoral Program in Chemical Engineering Department, Faculty of Engineering, University of North Sumatra, Medan, North Sumatera, Indonesia.

Hamidah Harahap, Lecturer of the Doctoral Program in Chemical Engineering Department, Faculty of Engineering, University of North Sumatra, Medan, North Sumatera, Indonesia.

Iriani, Lecturer of the Doctoral Program in Chemical Engineering Department, Faculty of Engineering, University of North Sumatra, Medan, North Sumatera, Indonesia.

Keywords: Temperature, pirolisis. Liquid smoke.

\section{INTRODUCTION}

Lignocellulose biomass is a renewable alternative that is widely available, can be used as a fuel, and is a potential raw material used in the chemical industry process of its renewable, low cost $\mathrm{CO} 2$ emission value. [1] Hazel Nut or Candle Nut (Aleurites moluccana) is classified as one of huge available natural resources in Indonesia, being considered as a wide prospect marketing commodity either domestic and overseas. Candle Nut shell resulted from its plantations is claimed as one of numerous solid waste biomasses, containing organic compounds such as hemicelluloses, cellulose, and lignin. [2] Pyrolised biomass resulted by means of thermal degrading in high temperature upon raw materials in a reactor isolated from oxygen or atmosphere, whereas liquid products in range $30 \% \mathrm{w}$ up to $70 \% \mathrm{w}$ averagely yielded. Pyrolysis also known as thermo chemistry technology to convert biomass on to energy sources and other chemical products comprising of liquid organic oil, organic ash and pyrolized gases.

Several parameters applied on pyrolysis influencing characteristics and applications of these products, i.e selecting in type of raw materials (biomass kinds, particle sizes, pretreatment of biomass, reaction's conditions (temperature, pressure, particles heating rate and contact durations), reactor configuration applied, due process and other variables such us extending catalysts and vapor condensing mechanism. [3] [4] Utilizing waste of biomass as the source of liquid smoke, thorough pyrolisis are commonly used. thus by using several raw materials such like coconut shells, palm stems, empty fruit bunches of palm , palm shell, saw dust, straw, wheat, grass,, pine nut shells, jatropha seeds, Karanja Niger seeds,, pine woods, corn cob, date seeds, coconut husks, plum seeds and waste residue. [2]

The use of lignocellulose residue raw materials from various food industries such as vegetable oil production, olive [5], soybean [5], oil palm empy fruit bunches [6], and fruit and grain shells [7], pistachio [8], Rice [9], among others, have been researched Extensive. As a result, pyrolysis products depend heavily on the raw material and process conditions used, the research results show that from 30 to 50 WT\% liquid smoke has a high oxygen content (between 25-40 WT\%) and water (between 2-50 WT\%). 10 


\subsection{Related Research}

Acetic acid compounds can occur from the pyrolysis process of hemiselolsa (Guo et all, 2013). According to Berry 2012 , acetic acid in the pyrolysis process can be produced from thermal decomposition of hemicellulose that occurs at $250 \mathrm{C}-350 \mathrm{C}$. The process of the formation of acetic acid occurs due to ring breaking of xylan compounds. In the GC-MS analysis, the formation of acetic acid compounds showed a percentage of $4.79 \%$ at $350{ }^{\circ} \mathrm{C}$. Furthermore, the temperatures increase of $450{ }^{\circ} \mathrm{C}$. The percentage of acetic acid of acquisition decreased to $3.65 \%$ and along with the temperature, increase of $550^{\circ} \mathrm{C}$ the percentage increase in acetic acid products was very significant reaching $7.84 \%$, this is due to the influence of ring breaking from degraded hemicellulose thermally form acetic acid compounds. At that temperature, the formation of acetic acid compounds also comes from the cellulose biomass component, which is degraded thermally to form acetic acid by the decarboxylation process. Marculescue et al, 2010 and Guo et al, 2011. Analyzing the process of cellulose pyrolysis undergoes various reactions including decarboxylation to produce hydrocarbon products, so that the formation in acetic acid compounds is formed at all temperatures and the highest percentage at a maximum temperature of 7, 84\% . Melisa ET. al., 2014, explained that the acetic acid produced from the pyrolysis process was formed from an acetylation reaction originating from hemicellulose compounds that were decomposed from a temperature of $230-350^{\circ} \mathrm{C}$.

\subsection{Proposed Method}

In the pyrolysis process, the hazelnut shell will undergo the breakdown of the chemical structure through the process of hydrolysis, primary decomposition, and repolymerization. The process of decomposition is influenced by the condition of the process and the material type of raw material affects the product composition as well as the characteristics of $\mathrm{PAH}$ formed. Liquid smoke has potensial for use sebagai bahan Baku pembuatan methanol, asam aseta, aseton, fenol baik dilakukukan secara ekstraksi, destilasi vakum, [11] sebagai bahan untuk flavour at food aplication [12] antiyoxidative and anti mikrob [13]. The smoking of meat [14] fresh fish preservative due to its antibacterial activity. [15] Latex coagulant.

\subsection{Reseach Methodology}

The purpose of this research was to know It is the objective of this study to report the characterization of the products from the pyrolysis of candel nut shell in order to define their potential as liquid smoke Sources and raw materials for the food industry. Product yields, composition of the liquid products (liquid smoke and tars) and the most relevant physicochemical properties were assessed and compared.

\section{EXPERIMENTAL}

\section{Collection and Preparation of Raw Material}

The preparation stage of raw material that includes preparing the raw material of hazelnut shell derived from pecans plantation in North Aceh district. Done drying under the sun for 2-3 days to keep water content $10-13 \%$. Then the process stage includes the process of thermal decomposition performed pyrolysis using fixed Bacth Reactor at a varied temperature at 350,450 and $550{ }^{\circ} \mathrm{c}$ and pressure of 1 (one) atmosphere as well as a variated pyrolysis time between 15 SD 425 minute and condenser temperatures range from $25-40{ }^{\circ} \mathrm{c}$. Further stage analysis analysis of the Yield of the overall liquid smoke products produced from the Pyrolisa process and identification of components contained in liquid smoke at optimum conditions.

\section{Proses pyrolysis}

The reactor was designed at $300 \mathrm{~kg}$ capacity and worked at a volume of $200 \mathrm{~kg}$ with the temperature of the cooling water kept steady at $28-35{ }^{\circ} \mathrm{C}$. by regulating the rate of flow of condensation water in and out. Pyrolysis tool uses a Double Unit Condenser System. Pyrolysis Process temperature varies at 350,450 and $550{ }^{\circ} \mathrm{C}$ and the time of pyrolysis presets i.e $15,30,4560$ and 425 minute. The condenser device used is equipped with 2 (two) parallel condenser system units. Furthermore, the product is analyzed at optimum conditions. The products produced from the pyrolsa process are in the form of 4 (four) types of products, namely Liquid smoke as the main product, Charcoal and Tar and a little non-condensable gas. For more details, the type of product produced in the pyrolysis process can be seen in Figure 1 below.

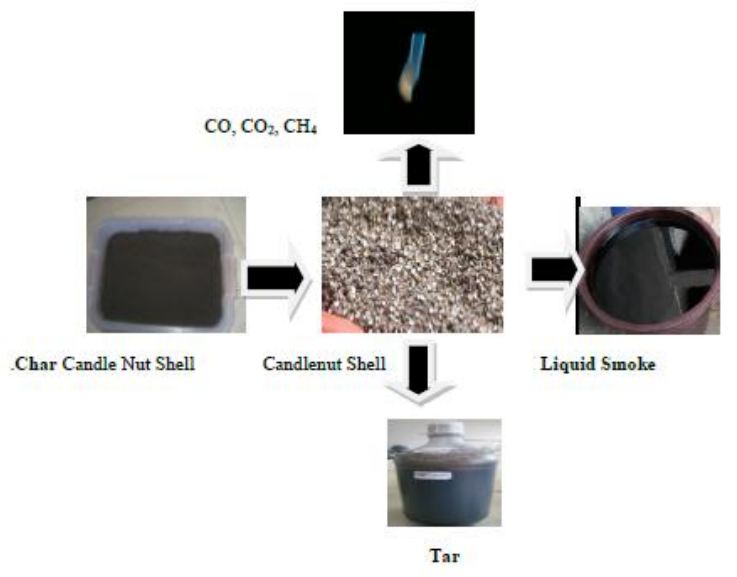

Figure 1. The product of the pyrolisis process of candle nut shell biomass

\section{RESULT AND DISCUSSION}

Effect of temperature and optimum time on liquid smoke composition

The GC-MS analysis data shows that the percentage of acetic acid occurs at high temperatures of $550{ }^{\circ} \mathrm{C}$ followed by temperatures of $350^{\circ} \mathrm{C}$ with levels of $4.79 \%$. This is in accordance with the statement of Guo ET all 2011, which states that the formation of acetic acid is influenced by the thermal decomposition that occurs in cellulose where lignin is in the temperature range of 350 to $550{ }^{\circ} \mathrm{C}$. According to Girad, that cellulose decomposes at a temperature of 200-350 ${ }^{\circ} \mathrm{C}$, while lignin is decomposed from 280 to $500^{\circ} \mathrm{C}$, so that the formation of maximum acetic acid compounds can occur at high temperatures up to below $550^{\circ} \mathrm{C}$ due to the interaction of components of cellulose and lignin compounds which undergo 
thermal decomposition in an integrated manner From the maximum levels that occur in the graph shows that the influence of temperature on cyclohexane compounds

The results showed that the highest levels of furfural compounds occurred at $550{ }^{\circ} \mathrm{C}$ with $13.39 \%$ levels. It is suspected that the thermal composition that occurs $450^{\circ} \mathrm{C}$ peak occurrence of furfural compounds which in addition obtained from the results of cellulose decomposition also other decomposition besides cellulose such as lignin. So that at $550{ }^{\circ} \mathrm{C}$ the furfural content continues to decompose but decreases more than $450^{\circ} \mathrm{C}$ whereas according to Guo et al., 2011 , it is stated that the formation of furfural compounds is influenced by cellulose and lignin decomposition at temperature intervals of 350 to $550^{\circ} \mathrm{C}$. So that the decrease that occurred in this study is the decrease in furfural compounds at a temperature of $550^{\circ} \mathrm{C}$ in accordance with the arguments of Guo et al., 2011. According to Melisa 2014, poliaromatic hydrocarbons are produced from lignin content, which undergoes a process of thermal decomposition at high temperatures to form venyl propane and subsequently undergo depolimesation or cracking processes whereby the results of the process can produce liquid smoke containing phenol, methane, acetic acid and poliaromatic hydrocarbon compounds.

Alternatively, even poliaromatic hydrocarbons can be derived from several compounds from the pyrolysis process produced such as guanicol, silingol, pharahidroxil phenol that undergo alkylation. From the results of GC-MS analysis carried out both at temperatures of $3500 \mathrm{C}, 4500 \mathrm{C}$ and 550 0C showed that the formation of poliaromatic hydrocarbons at optimum conditions did not occur. It can be seen in the composition of chemical compounds formed from the thermal decomposition process that occurs in each pyrolysis process of candlenut shell biomass at each temperature where there is no formation of PAH compounds such as benzo @ pirene. To find out the chemical components contained in liquid smoke, an analysis was carried out using a GC - MS tool. From Figure 4.8, 4.9 and 4.10 we can find out the number of component compounds and how the difference in the number of components in the candlenut pyrolysis at each pyrolysis temperature level can be seen in the graph below.

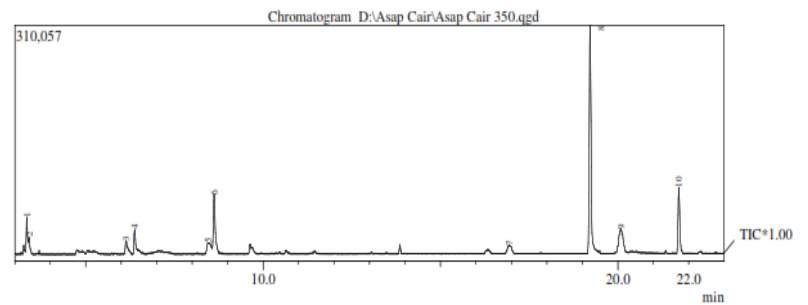

Figure 2. Graph Analysis of GC-MS Liquid Smoke at 350 0C

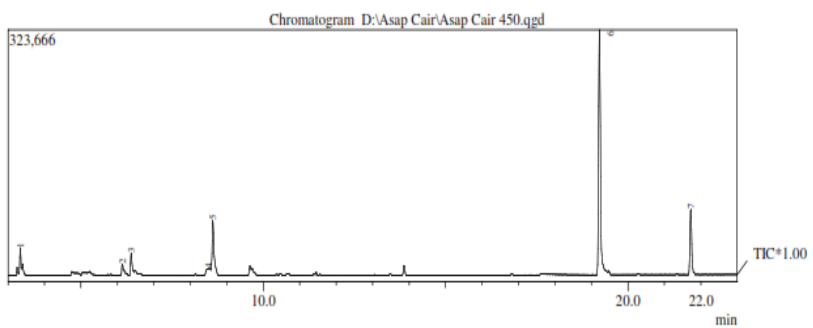

Figure 3: Graph Analysis of GC-MS Liquid Smoke at 450-0C

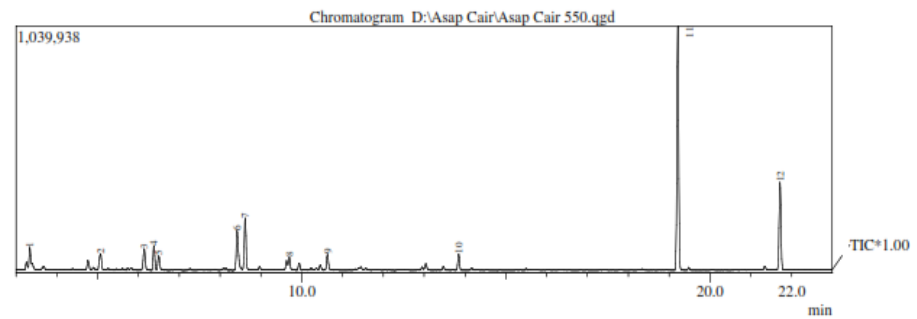

Figure 4, GC-MS Analysis Graph of Liquid Smoke at $550^{\circ}$

The results of the GC-MS analysis on the liquid hazelnut shell smoke from the pyrolysis process at 350, 450, $5500 \mathrm{C}$ are presented in tables $4.3,4.4,4.5$ below.

Table 1: Chemical composition of liquid hazelnut shell pyrolysis resulting from $350^{\circ} \mathrm{C}$

\begin{tabular}{|c|c|c|c|c|c|}
\hline No & $\begin{array}{l}\text { Name component } \\
\text { Coumpound }\end{array}$ & $\%$ Area & $\begin{array}{l}\text { Molecular } \\
\text { formula }\end{array}$ & $\mathrm{BM}$ & \\
\hline 1 & Cyclopenthanon & 5,13 & $\mathrm{C}_{5} \mathrm{H}_{8} \mathrm{O}$ & 84 & \\
\hline 2 & Cyclohexanone & 2,39 & $\begin{array}{l}\mathrm{C}_{6} \mathrm{H}_{12} \\
\mathrm{C} 6 \mathrm{H}_{12} \mathrm{O}\end{array}$ & $\begin{array}{l}84 \\
98\end{array}$ & $\begin{array}{l}3 \text { Hexene } \\
\text { Cyclohexanone }\end{array}$ \\
\hline 3 & 2 cyclopentene-1-one & 3,42 & $\begin{array}{l}\mathrm{C}_{5} \mathrm{H}_{6} \mathrm{O}_{3} \\
\mathrm{C}_{8} \mathrm{H}_{10} \mathrm{D}_{2} \mathrm{O}_{4} \\
\mathrm{C}_{5} \mathrm{H}_{6} \mathrm{O}_{2} \\
\mathrm{C}_{10} \mathrm{H}_{18} \mathrm{O}\end{array}$ & $\begin{array}{l}114 \\
172 \\
82 \\
170\end{array}$ & $\begin{array}{l}\text { 1,2 Dioxolan,3-one } \\
\text { 2-(4-nitro-phenyl) Acetamide } \\
\text { 2 Cyclopentene-1-one } \\
\text { 3,7-Octadiena-2,6-diol }\end{array}$ \\
\hline 4 & $\begin{array}{l}2 \text { methyl } 2 \text {-Cyclo } \\
\text { pentene } 1 \text { one }\end{array}$ & 4,81 & $\begin{array}{l}\mathrm{C}_{6} \mathrm{H}_{8} \mathrm{O} \\
\mathrm{C}_{5} \mathrm{H}_{8} \mathrm{~N} 2\end{array}$ & $\begin{array}{l}96 \\
96\end{array}$ & $\begin{array}{l}2 \text { methyl 2-Cyclopentene } \\
\text { 2,3diaza-bicyclo }(2,2,1) \\
\text { Heptene }\end{array}$ \\
\hline 5 & Acetic acid & 4,79 & $\mathrm{C} 2 \mathrm{H} 4 \mathrm{O}$ & 60 & Vinegar Acid \\
\hline 6 & fural Dehid & 11,91 & $\mathrm{C}_{5} \mathrm{H}_{4} \mathrm{O}_{2}$ & 96 & Fural \\
\hline
\end{tabular}


Influence Temperatur of Pyrolisis Process on Production of Liquid Smoke from Candlenut Shell by Examining its Potensial Coumpound

\begin{tabular}{|c|c|c|c|c|c|}
\hline 7 & $\begin{array}{l}\text { 1,2 Ethanodiol/ } \\
\text { Dipenil }\end{array}$ & 3,70 & $\begin{array}{l}\mathrm{C}_{9} \mathrm{H}_{5} \mathrm{NO} \\
\mathrm{C}_{14} \mathrm{H}_{14} \mathrm{O}_{2} \\
\mathrm{C}_{10} \mathrm{H}_{12} \mathrm{O} \\
\mathrm{C}_{7} \mathrm{H}_{1} \mathrm{O}\end{array}$ & $\begin{array}{l}153 \\
\\
214 \\
164 \\
\\
108\end{array}$ & $\begin{array}{l}6 \\
\text { (Dimethylamino)-3-methyl-3, } \\
\text { 5-hexadien-2-one } \\
\text { 1,2-Diphenyl-1,2-ethanediol } \\
\text {-6-(2-furanyl)-3-hydroxy-1,5- } \\
\text { hexadiene } \\
\text {-6-(2-furanyl)-3-hydroxy-1,5- } \\
\text { hexadiene }\end{array}$ \\
\hline 8 & 2 methoxy Phenol & 42,87 & $\mathrm{C}_{7} \mathrm{H}_{8} \mathrm{O}$ & 124 & o-Methoxyphenol Guasol \\
\hline 9 & $\begin{array}{l}\text { Valeranone- } \\
\text { netalenone }\end{array}$ & 9,51 & $\mathrm{C}_{15} \mathrm{H}_{26} \mathrm{O}$ & 222 & $\begin{array}{l}\text { 1(2H)-Naphthalenone, } \\
\text { Patchouli alcohol }\end{array}$ \\
\hline 10 & $\begin{array}{l}2 \text { methoxy } 4 \text { methyl } \\
\text { Phenol }\end{array}$ & 11,47 & $\mathrm{C}_{8} \mathrm{H}_{10} \mathrm{O}_{2}$ & 138 & $\begin{array}{l}\text { P-Cresol, 2-methoxy. } \\
\text { p-Cresol, 2-methoxy }\end{array}$ \\
\hline
\end{tabular}

From the results of pyrolysis obtained 10 components

of the ketone and aldehyde group, 3 components of the consisting of 2 components of the acid group, 2 components phenol group, and 1 component of the benzenol group.

Table 2 Chemical composition of liquid hazelnut shell pyrolysis resulting from $450{ }^{\circ} \mathrm{C}$

\begin{tabular}{|c|c|c|c|c|c|}
\hline No & $\begin{array}{l}\text { Name component } \\
\text { coumpound }\end{array}$ & $\begin{array}{l}\% \\
\text { Area }\end{array}$ & $\begin{array}{l}\text { Formula } \\
\text { Molecul }\end{array}$ & $\mathrm{BM}$ & \\
\hline 1 & $\begin{array}{l}\text { Cyclopentanone } \\
(\mathrm{CAS}) \text { Dumasin }\end{array}$ & 4,28 & $\mathrm{C}_{5} \mathrm{H}_{6} \mathrm{O}_{3}$ & 114 & \\
\hline 2 & $\begin{array}{l}\text { 2-Cyclopenten-1-one } \\
\text { (CAS) C 2- } \\
\text { (4-NITRO-PHENYL) } \\
\text {-ACETAMIDE } \\
\text { yclopentenone }\end{array}$ & 2,90 & $\begin{array}{l}{\mathrm{C} 6 \mathrm{H}_{6} \mathrm{O}_{2}} 6 \mathrm{H}_{12} \mathrm{O} \\
\mathrm{C}_{8} \mathrm{H}_{10} \mathrm{D}_{2} \mathrm{O}_{4}\end{array}$ & $\begin{array}{l}1141 \\
70\end{array}$ & $\begin{array}{l}\text { 3,7-Octadiene-2,6-diol, } \\
\text { 2,6-dimethyl- } \\
\text { 1,5-Octadiene-3,7-diol, } \\
\text { 3,7-dimethyl- } \\
\text { (3E)-2,6-Dimethyl-3,7-octadiene-2 } \\
\text {,6-diol }\end{array}$ \\
\hline 3 & $\begin{array}{l}\text { 2-Cyclopenten-1-one, } \\
\text { 2-methyl- }\end{array}$ & 4,26 & $\mathrm{C}_{6} \mathrm{H}_{8} \mathrm{O}$ & 96 & $\begin{array}{l}\text { 2-Methyl-2-cyclopentenone } \\
\text { 2-Methyl-2-cyclopentene }\end{array}$ \\
\hline 4 & Acetic acid & 3,65 & $\mathrm{C} 2 \mathrm{H} 4 \mathrm{O} 2$ & 60 & $\begin{array}{l}\text { Vinegar acid, Ethanoic acid Glacial } \\
\text { acetic acid }\end{array}$ \\
\hline 5 & $\begin{array}{l}\text { 2-Furan } \\
\text { carboxaldehyde } \\
\text { (CAS) Furfural }\end{array}$ & 13,39 & $\mathrm{C}_{5} \mathrm{H}_{4} \mathrm{O}_{2}$ & 96 & 2-Furaldehyde Fural Furole \\
\hline 6 & $\begin{array}{l}\text { Phenol, 2-methoxy- } \\
\text { (CAS) Guaiacol }\end{array}$ & 57,63 & $\mathrm{C}_{7} \mathrm{H}_{8} \mathrm{O}_{2}$ & 124 & o-Methoxyphenol Guajol Guasol \\
\hline 7 & $\begin{array}{l}\text { 2-Methoxy-4-methyl } \\
\text { phenol }\end{array}$ & 13,89 & $\mathrm{C}_{8} 10_{5} \mathrm{O}_{2}$ & 138 & $\begin{array}{l}\text { Phenol, 2-methoxy-4-methyl- } \\
\text { p-Cresol, 2-methoxy }\end{array}$ \\
\hline
\end{tabular}

Table 3 Composition of compounds formed as a whole from the thermal decomposition of the candlenut shell by the pyrolysis process.

\begin{tabular}{|l|r|r|r|}
\hline \multicolumn{1}{|c|}{ Komponen } & \multicolumn{2}{c|}{ Temperatur Pirolisis $\left({ }^{\circ} \mathrm{C}\right)$} \\
\hline Cyclopenthanon & \multicolumn{1}{|c|}{350} & \multicolumn{1}{c|}{50} & \multicolumn{1}{|c|}{550} \\
\hline 2 cyclopentene-1-one & 5.13 & 4.28 & 4.575 \\
\hline 2 methyl 2-Cyclopentene 1 one & 3.42 & 2.9 & 4 \\
\hline Acetic acid & 4.81 & 4.26 & 3.89 \\
\hline fural Dehid & 4.79 & 3.65 & 7.84 \\
\hline 1,2 Ethanodiol/ Dipenil & 11.91 & 13.39 & 8.55 \\
\hline 2 methoxy Phenol & 3.7 & 0 & 60.8 \\
\hline
\end{tabular}




\begin{tabular}{|l|r|r|r|}
\hline methoxy 4 methyl Phenol & 11.47 & 13.89 & 15.04 \\
\hline cyclohexanone & 2.39 & 0 & 0 \\
\hline Valeranone- netalenone & 9.51 & 0 & 0 \\
\hline 1 -hydroxy 2 propanon & 0 & 0 & 3.42 \\
\hline 1 hydroxy 2 butanon & 0 & 0 & 2.77 \\
\hline anyhdride Butanoid acid & 0 & 0 & 2.06 \\
\hline Propanol Acid & 0 & 0 & 2.72 \\
\hline Furan Metanol & 0 & 0 & 2.67 \\
\hline
\end{tabular}

Cyclopentanone is a compound formed from the pyrolysis process, at $3500 \mathrm{C}$ the resulting cyclopentanone content is $5.13 \%$ and a temperature increase of $450 \mathrm{OC}$ in the pyrolysis process affects the formation of cyclopentanone compounds by $2.30 \%$. At a temperature increase of $550^{\circ} \mathrm{C}$ the percentage increase in the formation of these compounds reaches up to $4.585 \%$. Furthermore, the formation of 1,2-ethanodiol-diphenyl compounds occurs at $350{ }^{\circ} \mathrm{C}$ at $11.91 \%$ and then an increase occurs to reach $13.39 \%$ which is the maximum product obtained in the thermal decomposition of candlenut shell biomass at $450^{\circ} \mathrm{C}$, and temperature increase of $550^{\circ} \mathrm{C} 1,2$ ethanodiol dipenyl product has decreased up to $8.55 \%$ which is the lowest product decrease of 1.2 ethanodiol dipenyl compound. From the graph above it can be seen that the effect of a temperature increase of 350 to $450{ }^{\circ} \mathrm{C}$ is the impact of the decomposition of cellulose, hemicellulose and lignin compounds so that the possibility of 1.2 ethanodiol diphenyl products also results from the decomposition of the three components of biomass

Methoxy phenol compound 2 is a group of phenol compounds formed from the thermal decomposition of biomass from lignin compounds that occur at temperatures of $280-500{ }^{\circ} \mathrm{C}$. This group of compounds is needed in the composition of liquid smoke compounds, in the graph shows that the composition of the highest 2 methoxy phenol compounds occurs at temperature of $450^{\circ} \mathrm{C}$ and lowest at $550{ }^{\circ} \mathrm{C}$, thermal decomposition of cellulose compounds has occurred at $350^{\circ} \mathrm{C}$ that is equal to $42,87 \%$, along with an increase in temperature, the formation of 2 methoxy phenol compounds is more perfect to occur until it reaches the percentage $5763 \%$ and at an increase of $550{ }^{\circ} \mathrm{C}$ the thermal decomposition of the lignin compound to form the 2 methoxy phenol compound was decreased due to a temperature of 450 ${ }^{\circ} \mathrm{C}$ the decomposition of the lignin compound had reached the point of perfection

Untuk lebih jelasnya efek suhu terhadap pembentukan senyawa pada proses pirolisis yang terdapat pada tiap suhu dapat dilihat pada gambar 4.7 dibawah ini.

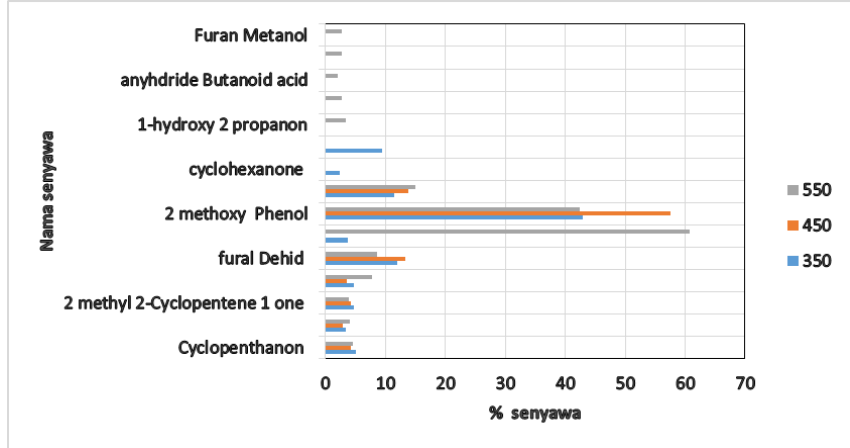

Figure 4. Graph of the effect of temperature on the composition of compounds contained at each temperature of the pyrolysis process Formation of 2 methyl 2-cyclopentene -1 one compound has occurred at a minimum temperature of 350 0C with the highest percentage value of $4.81 \%$ and decreased at $4500 \mathrm{C}$ and then again decreased at $5500 \mathrm{C}$ at $3.89 \%$, compound formation 2-methyl-2-cyclopentene 1 one occurs in the components of the biomass compound both from the components of the cellulose compound then hemicellulose and lignin due to the influence of the pyrolysis temperature which is able to make the composition of cellulose at temperatures of $3250 \mathrm{C}$ to $450 \mathrm{OC}$ and the thermal composition of cellulose that occurs at 325-450 $0 \mathrm{C}$ then hemicellulose 250-350 0C and lignin 350-500 0C are able to degrade these compounds to become pyrolysis products into liquid smoke. Here it shows that the formation of 2-methyl 2-cyclopentene - 1 one is possible for degradation of the three components of the compound.

\section{CONCLUSION}

From this research conclussion can be described as followes The best process condition of liquid smoke maximum during pyrolisis of candlenut shell by using pyrolisis methode at time 210 menute and Temperature 450 $\mathrm{C}$ and identification of products by using GCMS (GC Mass Spectrometry) at optimum condition at temperature $450{ }^{\circ} \mathrm{C}$. and time pyrolisis 210 menute is showed that liquid smoke candle nut shell. The 2- methoxy-4- methyl phenol is a type of phenol compound which is formed from the component of lgnin compound in the structure of the candlenut shell biomass compound. At $350{ }^{\circ} \mathrm{C}$ the formation of 2-methyl-4methyl phenol compound was $11.47 \%$ and increased by $13.89 \%$ at $450{ }^{\circ} \mathrm{C}$. And again at $550^{\circ} \mathrm{C}$ the increase in the compound is very maximum to reach $15.04 \%$. 
This shows that the formation of 2-methyl 4-methyl phenol compounds can occur from the contribution of decomposition of compounds mainly by decomposition of lignin compounds, as the most contributing to these compounds and subsequently occur from the contribution of cellulose and hemicellulose compounds. The effect of the temperature rise has a very large effect on the compound 2methoxy - 4- methyl phenol.

\section{ACKNOWLEDGMENTS}

The authors to thanks and respect to the Department of Research and Technology of Indonesia and KEMENRISTEK DIKTI who have contributed and supported in financial upon this research there bye accomplishing this research accordingly.

\section{REFERENCES}

[1] Czernik S, Bridgwater A. Overview of applications of biomass fast pyrolysis oil Energy Fuels 2004;18:590-8.

[2] Sulhatun, H. Rosdanelly, H. Hamidah, Iriani, ,'Improving production of Liquid Smoke from candlenut Shell By pyrolysis Proses. Emerald REACH Proceeding Series, 2017, Vol 1, pp 141-147DOI10.1108978-1-78756-793-1-00056

[3] Wei-Hsin Chen,Bo - Jhih Lin, 2015, Characteristics of products from the pyrolysis of oil palm fiber and its pellets in nitrogen and carbon dioxide atmospheres., Energy 94, 569-578

[4] A.V. Bridgwater 2010, Review of fast pyrolysis of biomass and product upgrading, Biomass and Bioenergy 38, 68-94

[5] Pütün A, Apaydin E, Pütün E. Bio-oil production from pyrolysis and steam pyrolysis of soybean cake: products yields and composition. Energy 2002;27:703-10.

[6] Khor K, Lim K, Zainal Z. Characterization of bio-oil: a by-product from slow pyrolysis of oil palm empy fruit bunches. Am J Appl Sci 2009;6:1647-52.

[7] Apaydin-Varol E, Pütün E, Pütün A. Rice slow pyrolysis of pistachio shell. Fuel 2007;86. 1892-1892.

[8] Pütün A, Apaydin-Varol E, Pütün E. Rice straw as a bio-oil source via pyrolysis and steam pyrolysis. Energy 2004;29:2171-80.

[9] Bertero M, Horacio A. Gorostegui, Camilo J. Orrabalis, Carlos A. Guzmán, Edgardo L. Calandri, Sedran U, Characterization of the liquid products in the pyrolysis of residual chañar and palm fruit biomasse. Fuel 116 (2014) 409-414

[10] Steven C. Ricke and Philip G. Crandall, 2014 " Fucntionally of Liquid Smoke as an all-natural antimicrobial in food preservation" Meat Science 97 197, 2016

[11] Chen, W. H. And Jhih Lin, B., 2015. Characteristics of products from the pyrolysis of oil palm fiber and its pellets in nitrogen and carbon dioxide atmospheres. Energy. 94 : 569-578.

[12] Satrijo Saloko, Purnama Darmadji, Bambang Setiadji, Yudi Pranoto “ 2014, " Antioxidative and antimicrobial activies of Liquid smoke nanocapsule using chitosan and maltodextrin and its application on tuna fish preservation.” Food Bioscience 7 , 71-79

[13] Afrizal fahlepy \& Didin suwardin, 2015, “ Characterization of iron metal corrosion in Liquid smoke coagulant, International Symposium on Aplied Chemistry 2015 (ISAC 2015), Procedia Chemistry 16, 420-426 